\title{
Progress and Challenges in
}

Transfusion Medicine,

Hemostasis,

and Hemotherapy

State of the Art 2008

41th Congress of the German Society for

Transfusion Medicine and Immunohematology

Editor

Rüdiger E. Scharf Düsseldorf

56 figures, 28 in color, 29 tables, 2008

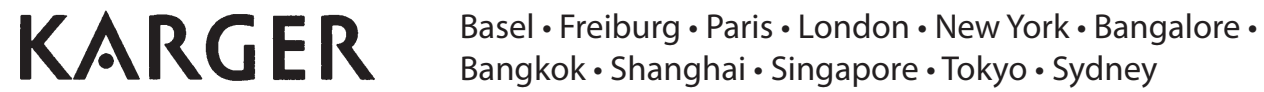




\section{Preface}

Conferences come and go. They take more than one year to be prepared but are over within a couple of days. By contrast, research communications and ideas being exchanged among scientists have a longer half-life. Consequently, congress attendees wish to receive take-home messages. To satisfy this demand, this volume gathers the contributions of the Plenary Lectures and State-of-the-Art Symposia speakers who presented at the Joint Congress 2008 of the German Society for Transfusion Medicine and Immunohematology (DGTI) and the Interdisciplinary European Society for Hemapheresis and Hemotherapy (ESFH) in cooperation with the Société Française de Transfusion Sanguine (SFTS), held in Düsseldorf from September 16 through 19, 2008.

The idea of publishing a State-of-the-Art book concomitantly to a congress is not new. It was Professor Marc Verstraete, the doyen among the European scientists in the field of thrombosis and hemostasis, who promoted this activity some 20 years ago at the congress of the International Society of Thrombosis and Hemostasis (ISTH) in Brussels. Since then, a long-standing tradition has been established among the ISTH members. This paragon has now been adapted for the participants of this DGTIESFH-SFTS meeting.

In the foreword of the Brussels State-of-the-Art book, Professor Verstraete once wrote, 'A preface is that part of a book that is placed first, written last, and read least'. Since all three statements he made are true, I will be brief. Transfusion medicine, hemostasis, and hemotherapy are relatively 'young' fields. They have in common both the subject 'blood' and the interdisciplinary approach. Thus, it is the translational impact of basic and clinical research that provides progress and challenges in patient care.

I am grateful to the authors, all experts in their field, who provided a chapter to this volume prior to the conference, meeting strict deadlines and accepting inevitable limitations in length, illustrations, and references. The support by our sponsors who made this project possible at all is particularly acknowledged, including CSL Behring, Wyeth, Baxter, NovoNordisk, and Novartis. Special thanks are also extended to the technical editing and production team of Karger publishers who worked hard to deliver this volume in due time. Finally, I would like to thank Uta Vandercappelle for her assistance, Nikola Möller for checking with me all manuscripts, and Anne Scharf for her coordination work as industrial liaison officer.

The editor hopes that the book will be received with the warmth and candor the authors deserve. To quote Professor Verstraete once more, 'History will tell, but obviously, the history we learn depends on who is the historian'. 


\section{Contents}

IX Preface

Social Intelligence and Competence

1 Increasing Safety by Implementing Optimized Team Interaction Experiences of the Aviation Industry

Müller, M.H. (Frankfurt/Main)

Karl Landsteiner Lecture

15 Allogeneic Hematopoietic Cell Transplantation - 2008: Achievements and Challenges

Blume, K.G. (Stanford)

Organ- and Vascular Bed-Specific Thrombogenesis

24 Endothelium and Hemostasis in Health and Disease

Steffel, J.; Lüscher, T.F. (Zurich)

37 Intravascular and Extravascular Coagulation and Fibrinolysis in the Diseased Lung

Markart, P.; Wygrecka, M.; Ruppert, C.; Korfei, M.; Dahal, B.; Jennes, T.;

Preissner, K.T.; Seeger, W.; Günther, A. (Giessen)

48 Interaction of Platelets and Inflammatory Endothelium in the Development and Progression of Coronary Artery Disease

Langer, H.F.; Gawaz, M.P. (Tübingen)

Hemostasis in Infection and Host Defense

60 Infectious Agents, the Contact System, and Innate Immunity

Frick, I.-M.; Herwald, H. (Lund)

$71 \quad$ Fibrinolysis and Host Response in Bacterial Infections

Bergmann, S.; Hammerschmidt, S. (Munich)

Immunomodulation and Therapeutic Apheresis

89 Selective Immune Apheresis Technologies - Where Do We Stand?

Ramlow, W.; Prophet, H.; Emmrich, J. (Rostock) 
113 Cytapheresis as a Nonpharmacological Therapy for Inflammatory Bowel Disease

Matsumoto, T.; Fukunaga, K.; Kamikozuru, K.; Tozawa, K.; Yokoyama, Y.;

Kusaka, T;; Onishi, K.; Miwa, H.; Nakamura, S. (Nishinomiya)

123 Immunoadsorption in Dilated Cardiomyopathy

Staudt, A.; Felix, S.B. (Greifswald)

Stem Cells and Blood Cell Engineering

132 Therapeutic Use of Circulating Peripheral Blood Stem Cells

Haas, R.; Bruns, I.; Kobbe, G.; Kronenwett, R. (Düsseldorf)

151 Cultured Red Blood Cells: A New Advance in Stem Cell Engineering Douay, L. (Paris)

162 From Hematopoietic Stem Cells to Megakaryocytes and Platelets

Favier, R. (Villejuif/Paris); Vainchenker, W. (Villejuif); Raslova, H. (Villejuif)

Molecular Immunohematology

178 The Bloodgen Project of the European Union

Avent, N.D. (Bristol)

189 Genotyping of Red Blood Cell, Granulocyte and Platelet Antigens:

Current Applications in the German-Speaking Countries

Flegel, W.A. (Ulm); Wagner, F.F. (Springe)

199 Molecular Methods in Immunohematology: Use of the PCR-SSP Technique

Prager, M. (Lich)

209 Fetal Blood Group Genotyping

Seltsam, A. (Hanover)

Platelet-Pathogen Interactions

219 Innate Immunity of Platelets: Specific Interactions with Viruses

Flaujac, C. (Boulogne/Paris); Boukour, S. (Paris); Cramer Bordé, E. (Boulogne/Paris)

234 Bacterial Contamination of Platelet Components: Prevalence and Measures to Prevent Transfusion-Transmitted Bacterial Infection

Corash, L. (Concord)

248 Clinical Experience with Pathogen Inactivation of Platelet Components for Transfusion Support

Cazenave, J.-P.; Waller, C.; Mendel, I.; Kientz, D.; Kandel, G.; Raidot, J.-P.;

Wiesel, M.-L.; Laforet, M.; Isola, H. (Strasbourg)

Diagnosis and Management of Bleeding Disorders

264 Acute Bleeding Complications: Pathophysiology, Diagnosis and Management Spannagl, M. (Munich) 
274 Challenges in Life-Threatening Hemorrhages: The Acquired Hemophilia Stockschläder, M.; Scharf, R.E. (Düsseldorf)

288 The Unrecognized von Willebrand Disease: A Frequent Cause of Bleeding Complications

Schneppenheim, R.; Budde, U. (Hamburg)

296 Acquired Platelet Function Defects: An Underestimated but Frequent Cause of Bleeding Complications in Clinical Practice

Scharf, R.E. (Düsseldorf)

Genetic Research and Challenges in Thrombophilia

317 Past, Presence, and Future of Genetics in Thrombophilia

Reitsma, P.H. (Leiden)

326 Thrombophilia and Vascular Complications in Pregnancy

Gerhardt, A.; Scharf, R.E. (Düsseldorf)

344 Prevention and Therapy of Pregnancy-Associated Thromboembolic Events Pabinger, I. (Vienna)

Novel Cellular Therapeutics

352 The Potential Role of Natural Killer Cells in the Treatment of Malignant Disease

Handgretinger, R.; Pfeiffer, M.; Teltschik, H.-M.; Feuchtinger, T.; Mueller, l.;

Lang, P. (Tübingen)

363 Current and Future Use of Dendritic Cells for Tolerance Induction

Hackstein, H. (Giessen)

373 Adult and Embryonic Stem Cell Therapy

Hescheler, J.; Spitkovsky, D. (Cologne)

Hemostasis-Navigated Hemotherapy

385 Hemostasis-Navigated Hemotherapy: Diagnosis, Management, and Monitoring of Patients with Active Bleeding

Pötzsch, B. (Bonn); Scharf, R.E. (Düsseldorf)

Demographic Changes and Blood Supply

394 The Impact of Demographic Changes on Transfusion Demand and Blood Supply: Need for Systematic Blood Donor Research

Greinacher, A.; Konerding, U.; Fendrich, K.; Alpen, U.; Hoffmann, W. (Greifswald)

403 Author Index

405 Subject Index 
$\Lambda \alpha \mu \pi \delta 1 \alpha \varepsilon \chi 0 \nu \tau \varepsilon \varsigma \delta 1 \alpha \delta \sigma o v \sigma ı v \alpha \lambda \lambda \lambda$ oı $\varsigma$

'Having Light We Pass It On To Others'

Plato, 'The Republic', 328a

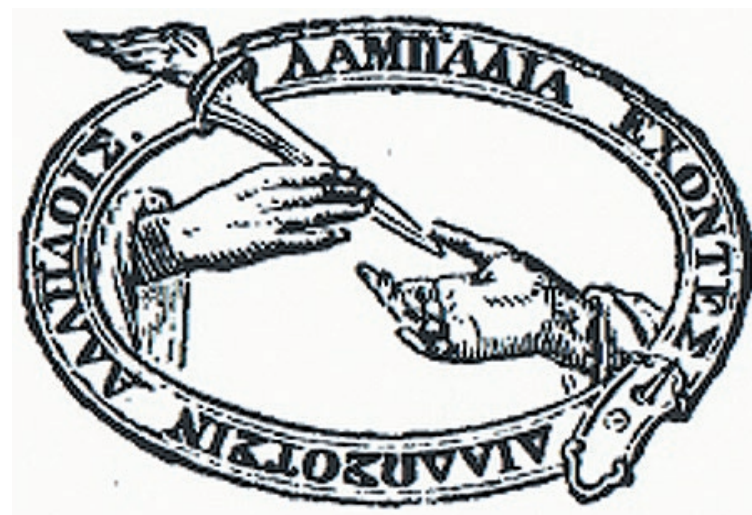




\section{Preface}

Conferences come and go. They take more than one year to be prepared but are over within a couple of days. By contrast, research communications and ideas being exchanged among scientists have a longer half-life. Consequently, congress attendees wish to receive take-home messages. To satisfy this demand, this volume gathers the contributions of the Plenary Lectures and State-of-the-Art Symposia speakers who presented at the Joint Congress 2008 of the German Society for Transfusion Medicine and Immunohematology (DGTI) and the Interdisciplinary European Society for Hemapheresis and Hemotherapy (ESFH) in cooperation with the Société Française de Transfusion Sanguine (SFTS), held in Düsseldorf from September 16 through 19, 2008.

The idea of publishing a State-of-the-Art book concomitantly to a congress is not new. It was Professor Marc Verstraete, the doyen among the European scientists in the field of thrombosis and hemostasis, who promoted this activity some 20 years ago at the congress of the International Society of Thrombosis and Hemostasis (ISTH) in Brussels. Since then, a long-standing tradition has been established among the ISTH members. This paragon has now been adapted for the participants of this DGTIESFH-SFTS meeting.

In the foreword of the Brussels State-of-the-Art book, Professor Verstraete once wrote, 'A preface is that part of a book that is placed first, written last, and read least'. Since all three statements he made are true, I will be brief. Transfusion medicine, hemostasis, and hemotherapy are relatively 'young' fields. They have in common both the subject 'blood' and the interdisciplinary approach. Thus, it is the translational impact of basic and clinical research that provides progress and challenges in patient care.

I am grateful to the authors, all experts in their field, who provided a chapter to this volume prior to the conference, meeting strict deadlines and accepting inevitable limitations in length, illustrations, and references. The support by our sponsors who made this project possible at all is particularly acknowledged, including CSL Behring, Wyeth, Baxter, NovoNordisk, and Novartis. Special thanks are also extended to the technical editing and production team of Karger publishers who worked hard to deliver this volume in due time. Finally, I would like to thank Uta Vandercappelle for her assistance, Nikola Möller for checking with me all manuscripts, and Anne Scharf for her coordination work as industrial liaison officer.

The editor hopes that the book will be received with the warmth and candor the authors deserve. To quote Professor Verstraete once more, 'History will tell, but obviously, the history we learn depends on who is the historian'. 